\title{
Going 'to paradise by way of Kensal Green': a most unfit subject for trading profit?
}

\author{
A J Arnold and J M Bidmead \\ University of Leicester
}

January 2008

Biographical note:

A J Arnold is Professor of Accounting and Business History in the School of Management,

University of Leicester.

$\mathrm{J}$ M Bidmead is an Honorary Research Fellow in the School of Management, University of Leicester. 


\title{
Going 'to paradise by way of Kensal Green': a most unfit subject for trading profit? ${ }^{1}$
}

\begin{abstract}
Since the Reformation, the established Church had monopolised the English burial trade. In London, in the 1830s, burial conditions posed a serious threat to public health and a number of limited liability companies were licensed by Parliament to provide new facilities for the interment of the dead on the edges of the city, before the main responsibility was then transferred to local government.
\end{abstract}

The paper examines the changes in government thinking that lay behind these policy shifts and explains why private sector capitalists were unable to meet the various expectations of customers in the London burial market, its own stakeholders and society more generally.

\section{Key words}

Burials

Public health

Joint-stock companies

Privatisation

Municipalities

Non-conformism

Cemeteries

Anatomists

Profit 
By the early nineteenth century, the authority exercised by the Established Church over the burial of the Christian dead on English soil, absolute since the Reformation, was beginning to break down, challenged as much by changing urban conditions and growing awareness of issues of public health as by the changes in religious practice embodied in non-conformism. Although the Church fought vigorously against the loss of its monopoly and the vital revenues associated with it, in London in the period 1832-41, six limited liability companies were licensed by Parliament to provide extensive new facilities for the 'interment of the dead' on the edges of the city, before these functions were transferred to the Metropolis itself in the $1850 s^{2}$

The decision of Parliament to look to private enterprise as the proper mechanism to discharge these responsibilities may seem surprising, and would soon be replaced by very different perspectives, but the shifts were in fact broadly consistent with changes in the thinking of the state at that time. This paper accordingly considers a number of important issues, widely debated in the mid-nineteenth century, concerning the proper treatment of the dead in crowded urban areas, whether burial was necessarily a sacred ceremony or whether enterprise mechanisms had a role to play and on the competing claims of alternative organisational forms, traditional, public and private, for the 'ownership' of the new social problems.

The next section considers burial policy and practices in London up to 1832, and the third examines the nature and extent of public health problems and of changes in government thinking concerning the alternative approaches to cemetery provision in the metropolis. The fourth examines the extent to which the companies concerned were able to satisfy the legitimate expectations of their stakeholders, the fifth considers their ability to meet social expectations concerning burial provision in central London and the final section provides some conclusions.

Three main factors affected the conditions in which mid-nineteenth century Londoners were obliged to bury their dead: the rise in urban population and the consequent pressure on burial space, changes in religious practice and the rise of non-conformism, and the influence of the medical profession and its desire to learn from the dissection of corpses. 
The overcrowding of London's graveyards had been noted as early as the seventeenth century. Pepys' diary entry for March $18^{\text {th }} 1664$ has him making arrangements for his brother's burial and grumbling at the state of affairs; 'So to my brother's, and to the church and with the grave-maker chose a place for my brother to lie in, just under my mother's pew. But to see how a man's tombes are at the mercy of such a fellow, that for $6 \mathrm{~d}$ he would (as his own words were), "I will justle them together but I will make room for him" speaking of the fullness of the middle aisle where he was to lie. And that he would for my father's sake do my brother that is dead all the civility he can; which was to disturb other corps that are not quite rotten to make room for him'. ${ }^{3}$

The diarist John Evelyn (1620 - 1706) also noted the congestion, describing the London churchyards as having 'dead bodies one above the other to the very top of the walls'. The New Churchyard had been established in 1569 outside Bishopsgate to take the overflow from the often tiny churchyards of the city and Bunhill (Bonehill) Fields, where the bones from the St. Paul's Cathedral charnel house had once been dumped by the cartload, had also been enlarged. Repeated outbreaks of plague exacerbated the problem and both Evelyn and Christopher Wren (unsuccessfully) proposed the creation of burial grounds outside the city. ${ }^{4}$

Burial practices changed gradually. Until the mid sixteenth century the usual custom was to bury the corpse in the graveyard uncoffined but wrapped in a winding sheet or shroud, the parish coffin only being used to transport the body to the graveside in a seemly manner. Though a person had the right to be 'returned to his parent earth for dissolution and to be carried thither in a decent and inoffensive manner ... the time must come when the posthumous remains must mingle and compose a part of that soil in which they have been deposited'. Coffins were otherwise reserved for vault burial within the church itself. This was not a common practice until well into the seventeenth century, although it later became a necessity for city churches, which sometimes took over the cellars of neighbouring properties when their own vaults were full. ${ }^{5}$

As the early Guilds and fraternities, that had once maintained the parish coffin, pall, cloaks, candles and hearse and provided the saying of mass for the souls of the poor, gave way to burial clubs and the carpenter and general craftsmen to the undertaker - the first recorded being William Boyce, in business around the Old Bailey in 1675 - funerals grew more elaborate through the eighteenth century and into the Victorian era. Coffin burials became customary and the coffins themselves more solid, inhibiting the natural dissolution of the body and taking up space needed for future generations. 
The major pressure on burial practice was, however, demographic change. In the middle years of the eighteenth century, the English population began to grow rapidly; from 5.7 million in 1750 , it reached 8.6 million in $1800,11.5$ million in 1821,15 million in 1841 and 16.5 million in 1850, at which time England had become by far the most densely populated of the major European powers. This growth was due not to immigration, but was 'largely determined by fertility changes', principally the effects of earlier marriage. At the same time, life expectancy was also increasing, from 36.8 years at birth in 1796 to 40.8 years in 1831. Life expectancy at birth in urban areas was distinctly lower than the national average although it did improve over time, in London from 30 years in 1811 to 33 years in 1841 and 39 years in $1871 .^{6}$

The effect of the unprecedented increase in population was accentuated by a major shift from rural areas to the towns and cities; in 1750 London $(675,000$ inhabitants) and Bristol $(50,000)$ were the largest cities in England, but by 1801 there were six with a population of 50,000 inhabitants (London 959,000, Manchester 89,000, Liverpool, Birmingham, Bristol and Leeds) and in 1851 there were twenty-nine cities in Britain with a population of 50,000, nine of which had a population of over 100,000. At the end of this period, more Britons were living in towns than in the country, one-third of them in cities of over 50,000 people. $^{7}$

This concentration of population growth in the urban areas caused the most severe social problems and life expectancies in the worst urban areas could be twenty years lower than in rural districts. Housing conditions were often appalling and drainage, sewage and water supply problems resulted in very poor standards of public health, with widespread disease, including the re-emergence of cholera in 1831. In 1840, London had a population of $1,870,727$ and, of the daily death rate of 125 , nine people a day died from old age and three from violence and most of the rest from disease in some form. The population was at its youngest in 1826 , when forty per cent of the population was under fifteen, but this did not lower the burial rate as much as might be assumed because the rates of death from disease were so high amongst children; 46 per cent of the total deaths in 1840 in London were children aged under fifteen. ${ }^{8}$

The consequences of these changes are vividly exemplified by experiences at two burial places within a hundred yards of one another in the London parish of St. Clement Danes. The parish acquired the Green Ground in 1638 as additional burial space before the area became fashionable and the open fields and gardens surrounding the burial ground were developed. The area later deteriorated into a slum and the Green Ground burial ground, hemmed in by crumbling tenement buildings and adjacent to a workhouse, was used by Dickens in Bleak House to symbolise corruption; this 'reeking tunnel of a court ... with every villainy of life in 
action close on death and every poisonous element of death in action close on life'. ${ }^{9}$ The Enon Baptist Chapel in Clements Lane, a hundred yards from the Green Ground, was opened primarily for dissenters in 1823, although it offered cheap burial for those of any denomination. This quickly became a scandal; 'nearly 12,000 bodies in wooden coffins had been buried in pits, the uppermost of which were separated from the worshippers by floorboards and a few inches of earth. Children attending Sunday school in the chapel were plagued by thousands of black flies, which had crawled out of the coffins beneath. The stench was often intolerable'. The problems were, in fact, even worse; many bodies had already been disposed of into the Thames, by means of the sewer over which the chapel had been built. $^{10}$

Up until the early 1800s it seems that the state of this and other inner London graveyards, malodorous neighbours to the living, so crowded that it was impossible to dig without disturbing other, recent graves, was noted but accepted as inevitable. By the 1820s, however, increasing concern for public health in towns was combining with an awareness that such things were better arranged in France, where their large cemeteries were situated outside the city boundaries. In London, the unsanitary conditions and the prevalence of fever in the immediate proximity of the graveyards were seized upon by many campaigners, including the proponent of the miasmic theory of disease, Dr. John Armstrong, who believed that the contagion from putrifying remains was born through the air via mists and foul vapours, rather than by water.

Change in religious attitudes was another major influence on burial practice. Although Henry VIII initiated the English Reformation by breaking with the Church of Rome, it wasn't until his death in 1547 that Protestant reform began to gather pace. Cranmer's Book of Common Prayer (1552) embodied, among other innovations, radical changes to the Order for the Burial of the Dead; the service itself was removed from the church to the graveyard and all evidence of the old belief in Purgatory and prayers for the souls of the dead was excised from the liturgy. Reforms were temporarily reversed under Mary (and their architect, Cranmer, burnt at the stake in 1556), but the developments were continued and consolidated through the Elizabethan period and accelerated during the Interregnum.

The eighteenth century brought the Enlightenment and, in some quarters, a turning away from superstition and intolerance; hellfire and fear of death retreated before the light of reason, benevolent angels increasingly replaced skeletons on funerary monuments and falling asleep, peacefully and eternally, became the dominant metaphor for dying. Life-spans lengthened as material prosperity, at least for some, increased; freed from, or deprived of, spiritual care for 
the immortal souls of their dead, the better-off sections of the population turned to the material world for consolation, relying on increasingly elaborate funerals and monuments to give meaning and direction to the process of mourning.

The eighteenth century also brought the rise of the dissenting religious groups that refused Anglicanism - Quakers, Baptists, Congregationalists, Episcopalians, Unitarians, Presbyterians and Methodists, these last being the largest group, with 76,000 members by the time of Wesley's death in 1791. These non-conformists appealed particularly to the working classes with their open-air sermons, lay preachers and emphasis on hard work and self-denial and were also linked to the new trade union movement and to other political groups like the Chartists. By the beginning of the nineteenth century these groups were large enough to influence changes in burial rites, the most important of which concerned the issue of consecrated ground.

Anglican churches had long provided, by law, burial for all Christians of whatever denomination in the consecrated ground of their graveyards and cemeteries. By the same law their clergy were forbidden to bury suicides or the unbaptised or to officiate on unconsecrated ground. The income generated by burial fees had always been important to church finances; in post-Reformation London, rates varied from parish to parish and within each parish according to a complex set of conditions, such as location of burial within the churchyard, coffined or sheeted burial, adult or child, parishioner or stranger. Sometimes these fees contributed directly to the income of the minister; responding to the tithe enquiry of 1638 , the minister of St. Botolph Aldgate explained that he depended on burial fees to the extent that 'I must say, if people do not die I cannot live'. ${ }^{11}$

Non-conformists resented having to pay parish rates and burial fees to enrich the Anglican Church, when their own ministers were unable to officiate at services on consecrated ground. Separate provision for dissenters was minimal; though Bunhill Fields was known as their burial ground, it was actually open to all, while graveyards attached to chapels were rare. In the early nineteenth-century, dissenters began to campaign for their own burial grounds; in 1819 the first non-denominational cemetery was laid out in Norwich and in 1820 a joint-stock venture founded a cemetery for Dissenters in Rusholm, Manchester. These were pioneering endeavours and provided, along with the French cemeteries, the models on which the first private cemeteries in London would be based.

The third strand in the web of circumstances surrounding the burial of the dead in nineteenth century London led from advances in medical knowledge to activities that were regarded with 
horror by most of the population, rich or poor, educated or ignorant. In order to learn their trade, students of medicine needed to dissect fresh corpses. The only lawful source of this commodity was the gallows and, since 1752 , not just any hanged felon (there were nearly a hundred capital offences on the statute books in 1823) but only those hanged for murder. ${ }^{12}$ Dissection had been the ultimate punishment for murder since the Murder Act of 1752, which stipulated that convicted murderers were to be hanged within 48 hours and dissected afterwards. $^{13}$

Later in the eighteenth century, when surgeon-anatomists had established schools of anatomy and lawful subjects for dissection were hard to come by, it was natural for entrepreneurs to step in and supply the market from a more convenient source, the graveyards, especially those of the large towns and cities where the anatomy schools themselves were situated. These entrepreneurs were the body snatchers or resurrection men; exemplars of an 'innovative market logic', their relations with their paying clients, the surgeons, were covert and uneasy and they were held in utter abhorrence by a public grown increasingly aware of their activities. Ruth Richardson, in particular, has studied the history and effects of grave robbery, especially on the poor, for it was the bodies of the poor, often buried in communal pits in flimsy coffins in the crowded inner city graveyards, that were the easiest targets for body snatchers. The example of Laurence Sterne illustrates the scope and efficiency of their operations; Sterne died in March 1768 and was buried in the graveyard of St. Georges, Hanover Square, apparently in a pauper's grave, in spite of his fame as author of the antinovel, Tristram Shandy. Four days later 'a professor of anatomy at Cambridge gave an illustrated lecture with a cadaver, which an acquaintance of Sterne's was shocked to recognise as the writer's corpse. Sterne was quietly reburied'. ${ }^{14}$

Undertakers and funeral directors moved in to provide those able to pay with the means to secure the bodies of their relatives against resurrectionist predations - triple coffins (wood, lead, wood), metal coffins, wooden coffins bound with iron, iron cages completely enclosing the coffin, huge weights over the grave - all costly solutions and in any case redundant after the period it took for a body to decay beyond the point of usefulness to anatomists. Guards could be set over the grave or the bodies stored in secure dead-houses for the necessary period, although all these solutions greatly increased the funeral expenses and none was proof against the possibility of bribes to replace bodies in the coffin by weights or sand or otherwise subvert the arrangements.

The poor, without access to expensive precautions, mixed the newly turned earth above the coffin with sticks and straw to impede the wooden shovels of the body snatchers, or they 
banded together in communal watch over their churchyard, or placed tiny unobtrusive markers on a grave to show whether it had been disturbed.

Human bodies were sold for fixed sums, sometimes by the inch, sometimes dismembered and sold limb by limb but, by a strange anomaly of the law, a dead person was no-one's property and so, in law, no theft was involved unless grave clothes had been taken along with the body. In 1822 William Cobbett noted the anomaly; 'to steal the body of a sheep, or pig, or calf, or ox, or fowl of any sort, is a capital felony, punished with DEATH, and ... to receive any such body, or to have it in your possession, knowing it to be stolen, is also a felony, punished with TRANSPORTATION' yet grave-robbery was treated leniently by judges. Vaughan, the London body snatcher, for example, received six months in prison for his part in multiple robberies from one Yarmouth graveyard (and his client, the eminent surgeon-anatomist Sir Astley Cooper, paid him an allowance during his sentence). Body snatchers had more to fear from the violence of outraged public feeling than from the Law; on at least one occasion, those caught in the act chose prison to save them from the mob. ${ }^{15}$

Public concern was growing. Feelings of outrage combined with distrust of the medical profession, willing participants, it seemed, in acts of desecration that offended against morality, decency and the natural human need to honour the dead. It was time something was done; in 1828, after years of lobbying from the Anatomical Society (formed by a group of eminent surgeon-anatomists), a Select Committee on Anatomy was appointed to investigate the supply of subjects for dissection with the object of presenting a Bill to Parliament.

Debate raged through the pages of the Times, the Lancet and other journals, bringing some very muddy prejudices to the surface in the process. The medical profession was unhappy about its association with the hangman and with the concept of dissection as punishment, the ultimate 'mark of infamy'. But if not the bodies of hanged murderers then whose bodies should be used? Many argued that the most convenient source of supply would be the unclaimed bodies of paupers, those who died in the workhouse without friend or relative to claim them (or at least, none who could afford to pay for a funeral). After all, as one observer pointed out, 'the unclaimed ... are mostly those whose lives have been vicious and characters abandoned - the prostitute, the vagrant, and the sot. If any are to suffer after death for the community, it should surely be those who have contributed evil rather than good to it when living'. Other medical men expressed horror at 'so degrading, and at the same time so uncalled for an expedient'. Cobbett used the columns of his Political Register to weigh in on the side of the poor; 'the unfortunate persons who die in poor houses and hospitals have, in numerous cases seen better days ... every working man ... pays full one-half of his wages in 
taxes and therefore, when he becomes so poor, helpless and destitute as to die in a poor house, it is unjust, cruel, barbarous to the last degree, to dispose of his body to be cut up like that of a murderer'. The objections of the poor to the fate prepared for them were the consequences, some claimed, of mere 'ignorance and prejudice'. The Paisley Reform Society presented a petition to Parliament which directly addressed this hypocrisy; 'the Petitioners respectfully suggest, that those whose education and habits have got the better of their prejudices may be called upon to make the sacrifice; if to come under the knife be of no consequence, why do medical men take such pains to be sheltered from its incisions? Surely it cannot be expected that the poor will be jeered out of their feeling of abhorrence for a system which the rich, the wise and the powerful take such extraordinary care to guard against'. ${ }^{16}$

One last terror was to be added to the disquiet of the time before the issue was settled. A pair of body snatchers was found to have taken the logical step of murder in order to provide their client-anatomist with really fresh subjects. In eleven months in 1827-28, Burke and Hare committed seventeen murders in Edinburgh and sold the corpses to Dr. Robert Knox of the Edinburgh Medical College. ${ }^{17}$ The first Anatomy Bill failed in the House of Lords in 1829, opposed by the Archbishop of Canterbury but, amid continuing controversy, a second Bill passed through Parliament, to become the Anatomy Act 1832, which permitted the bodies of the unclaimed poor to be taken for dissection.

\section{III}

During the eighteenth and nineteenth centuries, as 'most industries made the transition from mercantile to industrial capitalism by concentrating production', business and social life presented a series of major challenges. Some saw the solution as self-help and personal enterprise, at least on the part of those who already had some capital, the middle classes, but others increasingly looked to broader and more sophisticated organisational forms, particularly during the early years of the nineteenth century. Remarkable population growth in the urban areas brought real urgency to the question and there were wide-ranging public debates on who should 'own' these problems and how this ownership could be supported, encouraged and financed. ${ }^{18}$

Although the rapid changes were driven by the new manufacturing industries, these businesses typically required only modest amounts of capital and often continued to rely on 
the familiar mechanisms of family capitalism and local networks of personal acquaintance and trust. Instead, it was the infra-structural complexity of a rapidly urbanising Britain that provoked the more innovative responses and Foreman-Peck and Millward have argued that it was the 'network technology industries' in particular, with their large, sunk capital costs (relative to total costs) and need for unified systems that raised really 'distinctive problems' for government policy. ${ }^{19}$

Corporate personality, the existence of an organisation separate and distinct from its members, was a feature of several types of organization, such as the church, the craft guild and the town, well before its adoption by joint stock companies, although the ruin of the South Sea Company and the passing of the 'Bubble Act' of 1719-20 set back the possibilities for incorporation (by limiting the membership of a partnership to six and forbidding the formation of unincorporated joint-stock enterprises) until 1825, when the Act was repealed. Until the second half of the nineteenth century, companies could acquire their legal status, and the privilege of limited liability, only through Royal Charter (chartered companies) or by Act of Parliament (statutory companies). Over time, Parliament gradually widened its powers, including the granting of rights to limited liability but generally chose to restrict these accommodations to activities that both needed substantial amounts of capital and would provide considerable social benefit (and where compulsory powers over land acquisition, or digging up roads were involved). It was not until the passing of the Limited Liability Act 1855 and the Joint Stock Companies Act 1856 that limited liability companies could be formed by simple registration. ${ }^{20}$

In London the most important of the emerging, network technologies were the treatment and supply of water, with great potential for improving public health conditions and gas lighting (the early gas industry was far more concerned with lighting than with heating), also beneficial to public safety. Both technologies needed substantial amounts of capital to establish their networks. The first water company in London was the Chelsea Waterworks Company, formed in 1723, which drew water directly from the Thames and pumped the water to the slightly higher ground of the wealthy West End. There were serious concerns over the cleanliness of the water and further companies were approved by Parliament from 1806. The first company to be formed in the gas industry, the London Gaslight and Coke Company, was established in 1812 by Royal Charter and 'numerous companies were established during the $1820 \mathrm{~s}^{\prime}$ in the metropolis, mostly as statutory companies. ${ }^{21}$

Private enterprise was initially seen as the appropriate mechanism for the development of the urban water and gas industries, but 'competition, the accepted remedy for the evils of 
monopoly, was found to be unsatisfactory [and] the attitude of Parliament towards private enterprise in certain activities underwent a change during the 1830s and 1840s' as market and regulatory failures, or 'negative externalities', became apparent. A number of public health reports published in the early 1840 s 'demonstrated clearly the connection between bad water supplies and ill health' and indicated that the incentives that would motivate a private enterprise firm, for example to sell water, could not readily reflect the considerable social costs of deteriorations in public health caused by a lack of clean water or of fire damage if water was not readily available in (say) the poorer parts of town. It also became clear, at least in industries where infra-structural costs were so important to the volume of business activity, that competition caused considerable (and predictable) waste. In the gas industry, for example, the wasteful duplication of mains, the notoriously violent behaviour of the gangs installing the mains of rival companies and the repeated breaking up of roads came to discredit competition as the obvious mechanism for its development. An influential commissioners report written in 1847 concluded that 'the existence in the same town of two rival Gas Companies does not appear to us at all calculated to benefit the consumers'. Attempts to achieve a compromise position, by controlling the profit or dividend levels of private companies, also failed, in the face of a company's ability to make use of practices such as capital watering in order to negate the intended controls. ${ }^{22}$

At the same time that competition was seen to be failing, the municipalities were growing in stature. In the first quarter of the nineteenth century, population influxes had 'submerged traditional parish government in several cities including the crowded areas of the Metropolis' but there were major changes to the structure of English local government 'following the extensions of suffrage in 1832 to the middle class'. The treatment of the poor was transformed by the Poor Law Act of 1834 and the mechanisms of local government by the passing of the 1835 Municipal Corporations Act, although the latter did not apply to London. The municipalities were now able to respond directly to the needs of the local population and, after a number of survey officer reports on gas bills after 1845 criticised the pricing policies of private companies, the municipalities began to take over the responsibility for gas and water provision. In particular, they were able to set lower prices than commercial companies, in order to serve 'as many consumers as possible, at prices as near to the costs of production as can possibly be estimated'. ${ }^{23}$

Thus, what has been seen as a 'changing attitude towards municipal trading after the 1840s', as a belief in competition gave way to increased municipalisation and regulation was, as Matthews has argued, less a change in public attitude than a rational reaction to economic realities in the industries concerned. ${ }^{24}$ 
This was very much the case in London, even though it was 'left outside the range of the great local government reforms of 1835 and such pioneer social and administrative legislation as the Public Health Act of 1848'. Edwin Chadwick, Secretary to the Poor Law Commission, whose reports in 1843 and 1849 had helped to shape public opinion, was very much in favour of handing the control of London's water supply and health problems to a 'small executive Commission appointed by the Crown' and the Royal Commission on the Corporation of London in 1854 argued strongly that the creation of a 'gigantic new elected local authority for London was unwise and impractical'. This led to the passing of the Metropolitan Local Management Act of 1855, which placed most duties regarding sanitation and public health in the hands of a Metropolitan Board of Works. ${ }^{25}$

These general patterns, it will be argued, did not only affect the water supply and gas industries, or the 'network technology industries' more generally, because the defining characteristics that Foreman-Peck and Millward identify (high fixed costs, consequently lower unit costs the higher the volume of output and the absence of an effective second-hand market for asset sales such that investments were effectively 'sunk costs') could also be found in other businesses, including burial provision in the metropolis in the early nineteenth century. ${ }^{26}$

The debate about London's burial conditions intensified in the early 1830s. George Carden, a London barrister, had been an enthusiastic advocate of the French system on the Pere LaChaise model and he now persuaded several influential and wealthy Londoners to back a scheme for the purchase of land on the outskirts of the city for a cemetery that would provide security, space and peace in a tranquil landscape. Lobbying began straight away. ${ }^{27}$ The government was initially unmoved but an outbreak of Asiatic cholera and the return of the plague pit system of the 1660s to the capital in October 1831 brought added urgency to the debate and a Bill establishing a 'General Cemetery for the Interment of the Dead in the Neighbourhood of the Metropolis' was passed by Parliament in July 1832.

This encouraged other promoters and, by 1841, cemeteries had been established on the edge of the city by the following private sector companies (see Table 1 for details of the level of their shareholdings and for other financial information) : 
the General Cemetery Company, which established All Souls' Cemetery, Kensal Green Harrow Road, W.10, north of Notting Hill in 1833 [hereafter Kensal Green]; the South Metropolitan Cemetery Company, which set up the South Metropolitan Cemetery, Norwood High Street, S.E.27, near Lewisham in 1837 [Norwood]; the London Cemetery Company, which set up both St. James Cemetery, Swains Lane, Highgate N.6 in 1839 [Highgate] and All Saints' Cemetery, Linden Grove, Nunhead, S.E.15, south of New Cross in 1840 [Nunhead]; the West of London and Westminster Cemetery Company, which owned Brompton Cemetery, Old Brompton Road, S.W.5, between Kensington and Chelsea in 1840 [Brompton]; Abney Park Cemetery Company, which built Abney Park Cemetery South Lodge, Stoke Newington High Street, N.16, between Clapton and Holloway in 1840 [Abney Park] and the City of London and Tower Hamlets Cemetery Company, which established Tower Hamlets Cemetery, Southern Grove, Mile End, E.3, between West Ham and Stepney in 1841 [Tower Hamlets].

The Church of England, through its bishops, had expressed their concerns to the government at the potential threat to the burial fees paid to their parish churches and they duly announced that they would not consecrate any of the private sector cemeteries unless their right to burial income was legally guaranteed by suitable clauses in an enabling Act of Parliament. Only dissenters could be buried in non-consecrated ground and all but one of the companies were accordingly formed by Act of Parliament, so as to be able to offer Anglican burial services. ${ }^{28}$

Thus, the Bill whereby the General Cemetery Company was formed required the company to "reimburse the London parishes from which they had "poached" clients at up to 5 shillings per burial', close to the average burial fee in 1830-32 across several London parishes of $6 \mathrm{~s} 2 \mathrm{~d}$. The importance of burial fees to the parish clergy in London can be seen from the fact that they averaged about $£ 165$ per annum in the period $1838-40$, although varying enormously (from $£ 445$ to just under $£ 20$ ) from parish to parish. $^{29}$

The private sector London cemeteries offered far more space for burials than had previously been available in the city. The first, the 54 acre site at Kensal Green, was 'twenty times bigger than anything that had previously existed in London' and each of the other cemeteries was at least thirty acres in area, so that the collective provision was close to 300 acres. ${ }^{30}$ The General Cemetery Company had been established with an authorised capital of $£ 45,000$ in $£ 25$ shares and the other cemeteries required broadly similar amounts of financial support, ranging from $£ 35,000$ (in $£ 10$ shares) at Abney Park to $£ 75,000$ (in $£ 25$ shares) at Norwood. Land purchase 
costs were considerable but at least as much capital had to be spent on improvements to the sites so as to meet or even exceed public expectations. At Abney Park, for example, the land cost $£ 10,850$ and a further $£ 6,000$ had to be spent on roads and drainage. The General Cemetery Company spent about a fifth of its capital in purchasing, in September 1832, some fifty acres of heavy London clay hayfields in rural Middlesex for $£ 9,500$. The site, between the Harrow Road and the Grand Junction Canal, then had to be worked on, with payments of $£ 1000$ to the Grand Junction to 'turn the canal' and $£ 8,517$ to construct a suitable wall around the cemetery before the grounds could be consecrated and opened for business in January $18333^{31}$

As the disturbance of graves by body snatchers was a serious concern of the bereaved in the early years of the commercial cemeteries, high walls were standard, but were not always enough in themselves; at Norwood, the two-mile long, twelve-foot high brick wall was supplemented by the employment of a night-watchman, equipped with an alarm rattle that could be heard more than half a mile away. ${ }^{32}$ Drainage was also a problem, as each of the cemeteries was built on poor-draining London clay. This required the laying-in of quite elaborate drainage systems; at Abney Park, for example, good drainage was only achieved when a well-shaft 25 feet deep was sunk into the clay at the lower end of the site. ${ }^{33}$

All the cemeteries opened for business when their facilities were only partially complete, in order to establish some cash inflows before going on to complete the remaining building work. Thus, at Kensal Green, it took until July 1837 until the chapel, colonnade and catacomb had been built and the ground 'cleared of building materials of every description'. At Brompton, the promoters took over the site of a former brickfield in 1837 and began burials in 1840 but, three years later, twice the projected capital costs (of $£ 31,000$ ) had been spent without completing the original design. ${ }^{34}$ At Kensal Green, particular attention was paid to the architectural quality of the various buildings but the other cemetery companies also built chapels, colonnades and catacombs of great distinction. Highgate was noted for its extraordinary neo-Egyptian catacombs and at Brompton a splendid Anglican chapel was built, although lack of funds prevented the construction of the intended non-conformist and Roman Catholic chapels. The architect at Norwood was Sir William Tite, who worked in the Tudor Gothic style while, at Abney Park the architecturally distinguished site with its Egyptian Revival iron entrance gates was designed by Professor William Hosking. ${ }^{35}$

Most of the companies wanted to offer their customers a choice of burial in either consecrated or un-consecrated land, even though this complicated the layout of their cemeteries. Kensal Green, for example, set aside 15 of its 54 acres for dissenters with the remainder reserved for 
Anglicans, at Norwood about one-fifth of the site was kept for the use of non-conformists but at Nunhead only the north-west corner was kept for dissenters, while no more than five per cent of the early burials at Tower Hamlets, the most working class of the seven cemeteries, were made in un-consecrated ground. ${ }^{36}$

The Abney Park company, although formed in 1838-39 to 'provide a place of interment (removed from a crowded neighbourhood) for all classes of the community and all denominations of Christians' for the City of London and its eastern and north-eastern suburbs, was actually founded and promoted by Congregationalists who objected, as a matter of principle, to consecration. The company's founders were keen to avoid the segregation of Jews, Catholics and Dissenters from Anglicans, which would have 'marred [its] silent assembly of equals' and this stance proved popular with non-conformists, making it the logical successor to Bunhill Fields. It also meant that Abney Park's funerals could be cheaper than those of its competitors, which helped its business to expand rapidly once burials began in May 1840. The company also felt that the experiences of the first of the cemeteries at Kensal Green had demonstrated that the payment of "exorbitant fees to the clergy of those parishes whence the deceased had originated in order to make up their lost income from traditional burial rights ... and consecration by a bishop of the established church ... [were] Rituals which possessed neither basis in law nor conferred any spiritual advantages on the interred'. ${ }^{37}$

\section{IV}

This section of the paper examines the extent to which the private sector cemetery companies were able to satisfy the legitimate expectations of their stakeholders, across the period from the opening of the first, the General Cemetery Company, in 1833 until 1852, when the government passed the Burial of the Dead in the Metropolis Act, which enabled municipal Burial Boards to establish cemeteries and to begin to buy up private sector cemetery companies within the terms of the Metropolitan Interments Act of 1850.

The expectations of stakeholders reflect the purposes for which the business entity was created. Limited liability companies generally operate for the commercial benefit of their shareholders although they do also constitute a device that can be used mainly to promote the public good. Private cemeteries, primarily to meet the preferences of non-conformists, had already been opened in Liverpool, at the Necropolis in 1825 and at St James Cemetery in 1825-29 before any of the London cemetery companies were promoted and by 1830 , they 
were paying dividends of 12.5 and 8 per cent respectively, highly commercial rates of return for the time. ${ }^{38}$

Rugg has argued that it is a mistake to assume that, because nineteenth century cemetery companies paid out dividends, they were primarily profit-motivated. Cemetery companies in Britain, she argued, 'had a unique mixture of motivation for taking action' and each could, in principle, be located somewhere along an axis 'from the highest religious principles to basic commercial exploitation' although she also found it convenient for analytical purposes to allocate companies to one of three groups; those in which public health matters had priority, those founded by entrepreneurs wanting to exploit particular markets for burials and thirdly those enterprises set up to serve specific religious denominations. The likelihood of a given company being allocated to a particular group was itself influenced by the date it was formed; in the period 1820-38, the most important desires were to protect corpses from disturbance (particularly before the passing of Warburton's Anatomy Act in 1832, which ended the criminal trade in cadavers) and to meet the long-standing burial grievances of Dissenters, so that it was 'only in the mid-1830s that the purely speculative cemetery emerged...the new type of enterprise which appeared in 1835 was founded in the confident expectation of profit, since earlier companies had proved to be financially successful ... speculation in burials was a limited phenomenon, which affected London, Manchester and Scotland only ... [and] generally followed the periodic investment booms which occurred in the mid-1830s and mid1840s'. Rugg found that 32 per cent of private cemetery companies could be classified as being profit-motivated, including each of the London companies formed in the period 1832$41 .{ }^{39}$

In London, the sums of money needed for cemetery promotion were certainly beyond the reach of semi-charitable involvement. The promoters were often commercial rather than philanthropic people; Stephen Geary, for example, who promoted both the London Cemetery Company and the West of London and Westminster Cemetery Company, also built London's first gin palace and was as much an entrepreneur as an architect. Geary's successor, James Bunning, who was also surveyor to the Thames Tunnel and architect of the Coal Exchange, had a commercial outlook, as did the builder, Nowell who was a major investor in the Brompton cemetery and John Pirie, ship-owner and Mayor of London in 1841, who was one of the promoters of the Tower Hamlets cemetery. ${ }^{40}$ The South Metropolitan was also seen as having 'the intention of making profits by selling status burials, this time to the south of the river' and, more generally, the annual general meetings of each of the cemetery companies were entirely businesslike in the orthodox capitalist manner. ${ }^{41}$ 
Promoters of the time would have seen no particular contradiction between the seeking of commercial gains and providing for the public benefit, given the dominant features of the class system of that time. Wealth was concentrated in the hands of the middle and upperclasses; a pervasive route of modern capitalism, whereby profit is maximised by selling products and services to large numbers of working people with readily disposable spending power, was not then available and those who promoted the cemeteries would have seen the provision of burial facilities within a landscape that would appeal to middle-class sentiments (with some limited provision for common interment) as fully consistent with profit maximisation, since the poor had little spending power anyway. Those present at meetings of the cemetery companies were clearly aware that dividends would only be forthcoming if a good-quality public service was provided and Stephen Geary was quite explicit that the landscaping of the company's cemeteries at Brompton, Highgate and Nunhead and the construction of vaults and catacombs at the highest point of the last two grounds was 'vital to the success of the enterprise'. ${ }^{42}$

The promoters understood that theirs was an acutely sunk cost business that would only be profitable if there was a sufficient volume of demand; in May 1842 the directors of Kensal Green, for example, reported to their shareholders that they were going to offer seven acres of their land for the burial of the poor, as the land could support 133,500 graves, each of which would take ten coffins so that $1,335,000$ 'deceased paupers' could be provided for. Their commercial optimism was such that they could also point out that the land, 'at an average of 1000 burials a year will not be filled for 1,335 years' ${ }^{43}$ Cost-cutting was a regular response to insufficient profit levels; at Brompton in 1844, the directors both increased the charges for common interments and 'introduced the most rigid system of economy into the working department of the cemetery' while at Kensal Green the directors 'entered into a minute investigation of the several items of labour and expenditure connected with the cemetery' as it 'had been the constant object of the directors to keep down the expenses'. ${ }^{44}$

There were considerable variabilities in the trade that impacted on the financial returns that the individual cemeteries were able to generate for their investors. The burial fees themselves varied; the church of St. Mary, Stratford-le-Bow charged 12s for adult parishioner burials in its churchyard, Enon Chapel 14s, Spa Fields 14s, Abney Park 21s and Kensal Green and Brompton 25s. All charged more for private or brick graves and catacombs (Brompton, for example charged $£ 12$ for a place in its catacombs). Tower Hamlets required all corpses buried in their chapel vault to be in a lead coffin, or in pitch half an inch thick, between an interior and exterior coffin of wood. Even the size of graves was variable; most were $6 \mathrm{ft} 6 \mathrm{in}$ by $2 \mathrm{ft} 6 \mathrm{in}$ 
but they could be as much as $9 \mathrm{ft}$ by $4 \mathrm{ft}$, while the depth was anything from $7 \mathrm{ft}$ to $20 \mathrm{ft}$, with $10 \mathrm{ft}$ being common. ${ }^{45}$

These operational factors were of relatively modest significance in comparison with the initial investment decisions concerning the suitability and appeal of the proposed site to its future customers and the control of the related expenditures on buildings, drainage and the security of the site and the graves it would contain. Despite their ultimately commercial motivation, the private cemeteries took a long-term view of their prospects and there are few, if any, indications that they provided burial sites that were aesthetically unsatisfactory, particularly when compared with the old city graveyards. Each provided a large, relatively peaceful, garden-like area within which there was plenty of room for new burials for the foreseeable future. Inevitably, given their relative proximity to densely-populated urban areas, there were some variations in the detachment of the various sites from everyday life. The cemetery on Nunhead Hill, for example, was next to a small hamlet surrounded by market gardens and open fields and commanded splendid views of the city while Abney Park took over the site of two large seventeenth century houses and was able to supplement the existing plantings to such an extent that the resulting arboretum (of 2500 species, each named for the information of visitors) became a noted attraction; Kensal Green, however, was next to both a canal and railway company. Discussions ensured that these activities interfered as little as possible with the peace and quiet of the cemetery although in 1845 the ambience deteriorated somewhat when the proprietors were unable to prevent the construction nearby of a gasometer by the Western Gas Light Company. ${ }^{46}$

There was some variation in the 'market niche' that was sought by the various companies, although this was more a matter of emphasis than deliberate market segmentation, as catering for a range of burial preferences made obvious business sense. Tower Hamlets, the most working class of the cemeteries, was never seen as fashionable and provided mainly common interments for the local communities of Tower Hamlets, West Ham, Hackney, the City of London, Westminster and Holborn. Nunhead did not really cater for the burial of London's social elite but Kensal Green, on the other hand, was seen as a fashionable place of burial, attracted the 'cream of the West End trade' and would soon provide the first Royal burials in a commercial cemetery (two children of King George III, the Duke of Sussex in 1843 and Princess Sophia in 1848), although this did not discourage them from offering seven acres of their grounds to the adjacent parishes in 1842 on a long-term basis for the burial of the poor. ${ }^{47}$

In order to assess the level of business and the returns thereon that the private sector companies were able to generate, data was sought across the twenty-year period 1833 to 1852 . 
Relevant business records were obtained from both public depositories and private sources for four of the six companies, the General Cemetery Company (which opened its cemetery in 1833), the South Metropolitan Company, which began trading in 1837, the West of London and Westminster Company, which opened its cemetery at Brompton in 1840 (and was bought out by the government in 1852) and Abney Park (1840). ${ }^{48}$

The trade of companies in the cemetery business was generally quite stable year-on-year, once their trade had been properly established, although epidemics, economic recessions, severe winters and even fashion (the demand for catacomb burial surged in May 1843 after the first Royal burial in one of the commercial cemeteries) could influence the level of company incomes. Some growth of business could be achieved, particularly if burial fees were held down although there was a tendency for expenses, in which labour costs were the major element, to rise over time, particularly in response to higher volumes of business. Directors' fees at the cemetery companies were, however, usually payable only once dividends had reached 5 per cent per annum. ${ }^{49}$

Early experiences were generally encouraging. At Kensal Green a small dividend of 3 per cent was paid in June 1835, at which time the company's share price stood 12 per cent above par and by 1839, after its 'period of probation of seven years', it had arrived at 'that degree of prosperity which was held out at the commencement of operations'. This was reflected in a market price for their $£ 25$ shares of $£ 52$, a level that was maintained into the early 1850 s. The London Cemetery Company, with its cemeteries at Highgate and Nunhead, also 'appeared to do well' for the first twenty years of its existence. At Abney Park, the company 'prospered from the start', with 5000 burials in its first decade and more than two thousand a year during the early 1850 s, while even at Tower Hamlets, the least fashionable of the new cemeteries, the company was able to quickly build up its volume of business, particularly through common interments and Church of England burials. ${ }^{50}$

Table 1 shows the share capital, total capital, number of interments, revenues, expenses, profits and two rates of return for each of the companies concerned across the period 1833-52, as far as the available data permits. Rates of return have been defined as the rate of the profits to total shareholder capital invested in that business and/or as the rate of dividends to share capital (a close proxy thereto during the nineteenth century, when profit retentions were typically small). It took some while for the South Metropolitan Company to build up its trade at Norwood Cemetery and, over the period 1837 to 1852 , earned on average only 1.8 per cent a year, although there are clear signs of the company's improved profitability from the late 1840s. ${ }^{51}$ There are considerable gaps in the data for Abney Park, but in the period 1850-52, 
their dividends averaged 4.7 per cent (and would rise by the end of the 1850 s to 9 per cent a year). The General Cemetery Company was the most profitable of the four companies; it quickly established a commercial level of business and by 1845 was generally able to pay an annual dividend of 8 per cent, well above the rates that the railways were generally able to pay their investors. ${ }^{52}$

The government's initial response to the report of its Select Committee (the Chadwick Report) and other forms of lobbying, was to give General Boards of Health the power under the Metropolitan Interments Act of 1850 to purchase the existing commercial cemeteries. They duly selected the West of London and Westminster Cemetery Company, which owned Brompton cemetery, for their first compulsory purchase. This was a curious choice, despite the prosperity of the part of London in which the cemetery stood, as the company had experienced financial problems that had certainly not been hidden by its directors. Its operational costs were quite high, partly because of the steep rate of compensation the company was obliged to pay local clergy, which 'pushed up running costs, with Brompton having to pay 10 s per burial compared to only 5 s paid by Kensal Green', although far more important was the level of capital expenditure, relative to the revenue stream that it could generate. $^{53}$

Despite the involvement of experienced promoters, by 1841 the directors had accepted that the original capital of $£ 50,000$ was 'wholly insufficient to meet the expenditure required for completing the cemetery buildings'. The projected capital costs had been $£ 31,000$ but, even after the issue of $3000 £ 25$ shares (on which it had received $£ 63,500$ ) and the raising of loan finance of $£ 16,000$, the original design was still incomplete; if the Anglican chapel was undeniably splendid, the lack of funds prevented the construction of non-conformist and Roman Catholic chapels to provide for their other prospective customers. The government then tried to withdraw their offer, but the shareholders, who had received virtually no dividends since the formation of the company in 1840, prevented this. The government's offer of $£ 44,000$ was well below the (exaggerated) amount that the company claimed to have spent on capital items $(£ 148,000)$ but a more realistic figure of $£ 74,900$ was agreed upon after arbitration. $^{54}$

The available data on Brompton (see Table 1) is sketchy but is still sufficient to indicate the very real difficulties that the company faced. By 1849-51, the number of interments was twice that of the loss-making years of 1843-44 and revenues had increased similarly, but the company was still only generating receipts of 5.8 per cent on the capital invested; after deduction of necessary operating costs and the interest needed to service their loans, they 
were not going to be able to earn much more than 1.5 per cent a year on the capital they had spent, a third of the rate of return expected at that time for relatively low-risk commercial investments. The government compounded its error by making no attempt to buy any of the other cemetery companies, although the available evidence suggests that the West of London and Westminster Company, which owned Brompton Cemetery, was probably the least profitable of the companies, at least in the period before it was taken over by the government.

\section{$\mathbf{V}$}

Even after the private cemeteries had been built, the progress of reform was slow and protests continued to be made concerning burial conditions in the capital. The most eloquent voice belonged to the surgeon George Walker, whose early studies in Paris had first acquainted him with the French system. In 1839 he published Gatherings from Graveyards, a lurid and shocking account of his explorations of inner city burial grounds. He described the soil of the Green Ground as saturated with human putrescence, with human bones scattered on the surface (consequent upon the practice of re-using the coffin wood and metal fixings) and wrote of his visit to a Southwark graveyard, where 'a body partly decomposed was dug up and placed on the surface, at the side slightly covered with earth; a mourner stepped upon it, and the loosened skin peeled off, he slipped forward and had nearly fallen into the grave'. ${ }^{55}$

Walker's efforts were continually opposed by medical authorities with their own theories of disease to promote, by the vested interest of the Anglican Church (burial fees in London provided between a third and a half of clergy incomes) and even some non-conformist clergy fearful of the effect on their finances, but in 1842 a Commons Select Committee of Investigation upheld Walker's central argument, that interment in towns was detrimental to the health of the living.

The Benthamite reformer, Edwin Chadwick, was deeply involved with issues of public health. Appalled at the unsanitary and over-crowded burial-grounds of London, he opposed burials in towns and cities and advocated government intervention and the national provision of public cemeteries to provide burial facilities, particularly for those of more limited means. He strongly disapproved of the joint-stock company cemeteries as 'trading associations' that were bound to reject any improvements that did not promise an 'immediate return for the expense incurred'. In the early 1840s, Chadwick was appointed by the government to chair the Select Committee that published highly influential reports on the Improvement of the Health of Towns in 1842 and on the Results of a Special Inquiry into the Practice of Interment 
in Towns in 1843, providing evidence of the effects of poor drainage, sewerage arrangements and insanitary water provision on the conditions and health of poorer people in London and demonstrating the relationship between life expectancy and wealth and social class. ${ }^{56}$

The reports increased the opposition to burial in catacombs or vaults, although it seems to have been the recurrence of cholera in 1848 and its effects on the numbers of interments in London cemeteries that finally led to the closure of the Green Ground and other graveyards and to the first Public Health Act (1848). The Metropolitan Interments Act of 1850 forbade further burials in crowded churchyards but, by providing compensation to the Anglican clergy for the loss of burial fees and thus stifling their opposition, removed the greatest stumbling block to reform. The Act also gave General Boards of Health the power to provide burial grounds and purchase the established commercial cemeteries (see above), while the Burial of the Dead in the Metropolis Act of 1852 allowed the setting up of cemeteries (such as Camberwell Old Cemetery at Honor Oak) by Burial Boards. Although it did not prohibit the formation of further private cemetery companies, it did prompt the increased provision in the public sector that would quickly limit further growth in the private sector. ${ }^{57}$

\section{VI}

In the middle of the nineteenth century, the dominance of the established Church over English burials was challenged when the state looked initially to private enterprise and then to the municipalities as the appropriate mechanism to take over this responsibility. In the early years of the twentieth century, cremation, once shunned, began to provide a more fundamental solution to the needs of mourners in crowded urban areas where differing interests competed for scarce land resources. ${ }^{58}$

Since then, burial provision has been far less controversial although a number of inherent tensions have surfaced from time to time. The cost of graveyard maintenance, in the absence of recurrent payments by the bereaved, brought predictable problems and most of the private sector London cemeteries were, in the twentieth century, unable to meet their formal responsibility to keep cemetery, chapels and walls in 'thorough and complete repair', leading to accelerated physical deterioration, vandalism and the eventual purchase of the sites in the public interest by local authorities for modest or nominal sums, typically in the 1970s. ${ }^{59}$ In October 2004, a naval war veteran and his wife went to court to determine whether they had a right to burial in the local churchyard or whether the parochial church council was entitled to declare it full; under existing law, churchyards can be formally closed only by an Order of the Privy Council, signed by the Queen, on the ground that there is no longer space for burials 
and, once closed, churchyards cannot be re-opened. ${ }^{60}$ Even the activities of the early nineteenth century 'resurrection men', that so threatened the piece of mind of the bereaved, have recently returned to New York and sent 'shockwaves across America'; this time, organs and bones had been removed from perhaps a thousand corpses to meet the high demand for donated tissue in the medical transplant markets. ${ }^{61}$

Although some problems persist, considerable progress was made, particularly during the nineteenth century. In London, the official statistics of the time suggest that the rate of death, from a population of $1,870,700$, approached 45,000 a year. Overcrowding in the small churchyards had produced conditions that posed a clear 'threat to both health and adjacent property', while the larger burial-grounds at Bethnal Green and Bunhill Fields had already absorbed nearly 150,000 bodies into their 6.5 acres, so there was clearly the most urgent need for additional resources to be made available. ${ }^{62}$

The willingness of private entrepreneurs to ease the overcrowding problems by opening large, new cemeteries on the city margins, without need for the state to raise taxes at a time when it was facing major constitutional problems, must have seemed welcome indeed. ${ }^{63}$ At this time, the sanctioning of limited liability companies by Act of Parliament had already proved satisfactory as a mechanism by which to develop the canals and had recently been used for the new 'network industries', gas lighting and water supply, and its extension to a different type of urban problem, burial provision, must have seemed logical, if risky given the religious and personal sensibilities involved.

The new companies certainly offered a significant amount of additional space for burials; the first to open was twenty times larger than any other burial ground in London and collectively, the private sector made available nearly 300 acres on the edges of the city. In the early 1840 s, even before some of the new cemeteries were fully operational, the private sector was providing 3,335 burials a year, 7 per cent of the total, and by 1854 they were meeting about a quarter of London's needs (with plenty of spare capacity in hand), thereby allowing the government to close down the most crowded parochial burial-grounds. ${ }^{64}$

The persistence of appalling conditions in the city churchyards and chapels into the 1840s was a cause of great social concern. The private companies were also criticised, in spite of their efforts, on the grounds that burial provision was an 'unfit subject for trading profit', that the cost of their funerals was 'iniquitous' and, by implication, that their profit levels were too high. The last two perspectives did not, however, entirely match up. A substantial proportion of the total cost of a funeral consisted of the payments made to stone-masons and undertakers; 
by the 1840 s, the latter were charging $£ 50-70$ for an 'ordinary' middle-class funeral, although the growing public taste for such items as black ostrich feathers and white silk winding-sheets and gloves could quickly raise this to $£ 120-30{ }^{65}$

The somewhat sentimental assumption that the commercial provision of activities that are morally objectionable, at least to some people, is necessarily highly lucrative has not been confined to Victorian observers; even in the 1990s, Rugg was able to conclude that 'immense profits ... were to be had from burials' whereas, as this paper has shown, the reality was rather that the private companies offered an expensive and not particularly profitable service (consequent on an average cost per cemetery of around $£ 65,000$ ) that was effectively confined to middle-class sensibilities and pockets. ${ }^{66}$

Furthermore, soon after the private cemetery companies were established, the deficiencies of competitive mechanisms in the urban water and gas industries began to emerge and the attitude of Parliament towards private enterprise changed quite quickly. The municipalities grew in stature at this time, partly because as they took over gas and water provision, they proved far more responsive to local needs and generally set much lower prices than the commercial companies. When the local authority took responsibility for burial provision in London, they were able to establish cemeteries for 'around $£ 20,000$ ', less than a third of the average cost in the private sector and this helped them to provide decent burials at a cost with which the poor could cope and of a simplicity that suited the tastes of Dissenters. ${ }^{67}$ The decision to transfer responsibility for urban burials away from the private companies to the municipalities was thus in large part a political decision, a recognition that 'cemeteries could not be regarded for long as oases of peace for the dead of the privileged classes' and that the working classes needed to be able to bury their dead at prices they could afford. ${ }^{68}$

The initial support of government for the privatisation of London cemeteries and its subsequent conversion to the merits of municipalisation are fully consistent with changes in the government thinking of that time concerning the major new urban utilities, gas lighting and water supply. The argument in this paper is that the defining characteristics that ForemanPeck and Millward attribute to 'network technology industries' of the time (high fixed costs, consequently lower unit costs the higher the volume of output and the absence of an effective second-hand market for asset sales such that investments were effectively 'sunk costs') were also present in other trades and indeed provide an appropriate framework for understanding the changing patterns of responsibility for cemetery provision in the Metropolis in the first half of the nineteenth century, despite the very different problems and sensibilities that burial involves. 


\section{Acknowledgements}

The authors would like to thank David Burkett, Company Secretary to the General Cemetery Company, Jon Newman and Graham Gower of Lambeth Archives for their help in accessing archival materials used in this paper and two anonymous referees for their helpful comments on an earlier version of the paper.

\section{References}

\section{Archival:}

General Cemetery Company: annual reports 1834-90, General Cemetery Company offices.

West of London and Westminster Cemetery Company: minute books, 1839-54 WORK 6/65-67; Public Records Office, Kew

South Metropolitan Cemetery Company: ledger 1837-1873 IV/100/AD/3/1;

minutes of general meetings and annual accounts 1864-1915 IV/100/AD3/1-2; Lambeth archives

Abney Park Cemetery Company: annual accounts 1882-95 D/B/ABN/1/26;

minute books of directors 1850-79 D/B/ABN/1/1-2; Report on Burial Acts 1852-90 ABN/1/56;

Hackney archives. Papers of company BT 41/3/12; Public Records Office, Kew

\section{Secondary:}

Arnold A J and S McCartney, 'Were they ever "productive to the capitalist"? Rates of return on Britain's railways, 1830-55', Journal of European Economic History, Vol. 33 No 2, (2004): 383-410

Briggs A, Victorian Cities, London: Pelican, 1971.

Cottrell P L, Industrial Finance 1830-1914, London: Methuen, 1980.

Coutts J, 'Points of Entry: Kensal Green Cemetery', History Today, Vol. xlii (1992): 62-63.

Curl J S, 'Nunhead Cemetery, London', Ancient Monuments Society Transactions, n.s. Vol xxii (1977): 28-89.

Curl J S, 'The Design of the Early British Cemeteries', Journal of Garden History, Vol. 4 No. 3 (1984): 223-54.

Curl J S, The Victorian Celebration of Death, Stroud: Sutton, 2000.

Curl J S, Kensal Green Cemetery, Chichester: Phillimore, 2001.

Edwards J R, A History of Financial Accounting, London: Routledge, 1989.

Falkus M E, ‘The British gas industry before 1850’, Economic History Review Vol 20 (1967): 494-508.

Falkus M E, 'The development of municipal trading in the nineteenth century', Business History Vol 19 (1977): 134-61.

Finer H, Municipal Trading, London: Allen and Unwin, 1941.

Foreman-Peck J and R Millward, Public and Private Ownership of British Industry 1820-1990, Oxford: Clarendon Press, 1994

Friends of Nunhead Cemetery, Nunhead Cemetery: Illustrated Guide, London: Nunhead Cemetery, 1988. 
Guardian, The

Harding V, 'And one more may be laid there: the Location of Burials in Early Modern London', London Journal Vol. 14 No. 2 (1989): 112-29

Hobsbawm E J, Industry and Empire, London: Penguin, 1969.

Holmes B, The London Burial Grounds, London: T Fisher Unwin, 1896.

Hunt B C, The Development of the Business Corporation in England 1800-1867, Cambridge MA: Harvard University Press, 1936.

Jalland P, Death in the Victorian Family, Oxford: Oxford University Press, 1996.

Joyce P, A Guide to Abney Park Cemetery, London: Abney Park Cemetery, Second Ed., 1994.

Jupp P C, 'Enon Chapel: No Way for the Dead' in P. C. Jupp and G Howarth (Eds), The Changing Face of Death: Historical Accounts of Death and Disposal, Basingstoke: Macmillan, 1997: pp. 90-104.

Jupp P C and C Gittings, Death in England: an Illustrated History, Manchester: Manchester University Press, 1999.

Keeling D F, 'The City of London and Tower Hamlets Cemetery', East London Papers, Vol XII, 1969: 118-28.

Kiloh G, 'A Corner of London, the Heart of the Campus', LSE Magazine Vol 18 No 1, 2006: 15-17.

Lambeth Borough, West Norwood Cemetery, London: Lambeth Borough, 1971.

Latham R, The Illustrated Pepys, London: Bell and Hyman, Second Ed. 1982

Manning G, The Listed Structures in West Norwood Cemetery, London: Norwood Society, 1989.

Matthews D, 'Rogues, speculators and competing monopolies: the early London gas companies, 18121860', London Journal, Vol 11 (1985): 39-50.

Matthews D, 'Laissez-faire and the London gas industry in the $19^{\text {th }}$ century: another look', Economic History Review, Vol 39 No. 2 (1986): 244-63.

Meller H, London Cemeteries, Aldershot: Ashgate, Third Ed. 1999.

Observer, The

Patterson M and D Reiffen, 'The Effect of the Bubble Act on the Market for Joint Stock Shares', Journal of Economic History, Vol L Part 1 (1990), 163-71.

Pinfold J, 'The Green Ground' in P. C. Jupp and G Howarth (Eds), The Changing Face of Death: Historical Accounts of Death and Disposal, Basingstoke: Macmillan, 1997: 76-89.

Report on the Improvement of the Health of Towns. Effect of Interment of Bodies in Towns, BPP (1842) $327 \mathrm{X}$

Report on the Sanitary Conditions of the Labouring Population of Great Britain. A Supplementary Report on the Results of a Special Inquiry into the Practice of Interment in Towns (Chadwick Report), BPP (1843) 509 XII

Return of all Burial Grounds still open for Interments within the limits of the Burials within the Metropolis Act BPP (1854-55) 239 LIII

Richardson R, Death, Dissection and the Destitute, London: Routledge, 1987. 
Ross Williamson R P, 'Victorian Necropolis: the Cemeteries of London', Architectural Review, Vol. X 1942: 87-96.

Rugg J, The Rise of Cemetery Companies in Britain, 1820-52, Unpublished PhD, University of Stirling, 1992.

Rugg J, 'The Origins and Progress of Cemetery Establishment in Britain' in P. C. Jupp and G Howarth (Eds), The Changing Face of Death: Historical Accounts of Death and Disposal, Basingstoke: Macmillan, 1997: 105-119.

Schofield R, 'British population change 1700-1871', in R Floud and D McCloskey (eds), The Economic History of Britain since 1700, Vol 1: 1700-1860 (Second ed.), Cambridge: Cambridge University Press, 1994: 60-95.

Smellie K B, A History of Local Government (Fourth ed.), London: Allen and Unwin, 1968.

Smith E E F, 'The South Metropolitan Cemetery, West Norwood', Collectanea Londoniensia (London and Middlesex Archival Society Special paper) No 2, 1978: 436-38

Stephenson R, ‘Brompton Cemetery’, Necropolis News Vol. 4 No. 1 2002: 3-8.

Times, The

Walker G A, Gatherings from Grave Yards; particularly those of London, London: Longman, 1839.

Whitfield P, London: a Life in Maps, London: British Library, 2006.

Wilkins R, 'Premature burial and body snatching', Necropolis News Vol. 1 No. 2 1993: 11-14

Wilson J B, 'Norwood Cemetery', in J B Wilson (Ed.), The Story of Norwood, London: Norwood Society, 1990: 17-19.

Wilson J F, British Business History, 1720-1994, Manchester: Manchester University Press, 1995 
Table 1: London cemetery company rates of return and dividend, 1833-52

\begin{tabular}{|c|c|c|c|c|c|c|c|c|}
\hline Year & Share capital & Total capital & $\begin{array}{l}\text { Interment no } \\
\text { (or £ fees) }\end{array}$ & Revenue & Expenses & Profit & $\begin{array}{c}\text { RoR } \\
\%\end{array}$ & $\begin{array}{c}\text { Divis } \\
\%\end{array}$ \\
\hline GENERAL & CEMETERY & COMPANY & & & & & & \\
\hline 1833 & & & 84 & & & 150 & & 0 \\
\hline 1834 & 45000 & 45651 & 197 & & & 501 & 1.1 & 0 \\
\hline 1835 & 45000 & 45203 & 360 & 3241 & 2339 & 902 & 2.0 & 3.0 \\
\hline 1836 & 45000 & 45103 & 427 & 4918 & 2768 & 2150 & 4.8 & 5.0 \\
\hline 1837 & 45000 & 46072 & 677 & 6425 & 3206 & 3219 & 7.0 & 5.0 \\
\hline 1838 & 45000 & 46176 & 787 & 6756 & 3952 & 2804 & 6.1 & 6.0 \\
\hline 1839 & 45000 & & 900 & & & & & 6.0 \\
\hline 1840 & 45000 & & 900 & & & & & 6.0 \\
\hline 1841 & 45000 & & 900 & & & & & 6.0 \\
\hline 1842 & 45000 & & 900 & & & & & 6.0 \\
\hline 1843 & 45000 & & & & & & & 6.0 \\
\hline 1844 & 45000 & & & & & & & 7.0 \\
\hline 1845 & 45000 & & & & & & & 8.0 \\
\hline 1846 & 45000 & & & & & & & 8.0 \\
\hline 1847 & 45000 & & & & & & & 8.0 \\
\hline 1848 & 45000 & & & & & & & 8.0 \\
\hline 1849 & 45000 & & & & & & & 8.0 \\
\hline 1850 & 45000 & & & & & & & 8.0 \\
\hline 1851 & 45000 & 50845 & & & & & & 7.5 \\
\hline 1852 & 45000 & 51178 & & & & 3708 & 7.2 & 8.0 \\
\hline SOUTH & METROPOL & CEMETERY & COMPANY & & & & & \\
\hline 1837 & 24900 & 24961 & & & & 61 & 0.2 & \\
\hline 1838 & 57466 & 57813 & $\begin{array}{l}£ \quad 63 \\
\end{array}$ & & & 306 & 0.5 & \\
\hline 1839 & 68475 & 69013 & $£ 156$ & 1018 & 847 & 171 & 0.2 & \\
\hline 1840 & 68475 & 68714 & $£ 272$ & 1790 & 2089 & -299 & -0.4 & \\
\hline 1841 & 72000 & 72326 & $£ 527$ & 3160 & 3073 & 87 & 0.1 & \\
\hline 1842 & 72000 & 72870 & $£ 579$ & 3055 & 2511 & 544 & 0.7 & \\
\hline 1843 & 72000 & 73024 & $£ 770$ & 3771 & 2753 & 1018 & 1.4 & \\
\hline 1844 & 72000 & 73248 & $£ 918$ & 4164 & 3076 & 1088 & 1.5 & \\
\hline 1845 & 72000 & 73889 & $£ 1005$ & 4686 & 2965 & 1721 & 2.3 & \\
\hline 1846 & 72000 & 73804 & $£ 1047$ & 4710 & 2995 & 1715 & 2.3 & \\
\hline 1847 & 72000 & 74184 & $£ 1135$ & 5734 & 3554 & 2180 & 2.9 & \\
\hline 1848 & 72000 & 74227 & $£ 1369$ & 5597 & 3394 & 2203 & 3.0 & \\
\hline 1849 & 72100 & 74028 & $£ 1336$ & 5273 & 3412 & 1861 & 2.5 & \\
\hline 1850 & 72500 & 76371 & $£ 1997$ & 7809 & 3991 & 3818 & 5.0 & \\
\hline 1851 & 72500 & 74748 & $£ 1521$ & 5412 & 3410 & 2002 & 2.7 & \\
\hline 1852 & 72500 & 75455 & $£ 1759$ & 6149 & 3267 & 2882 & 3.8 & \\
\hline WEST OF & LONDON & CEMETERY & COMPANY & & & & & \\
\hline 1840 & & & & & & & & \\
\hline 1841 & 63500 & & 190 & 802 & & & & \\
\hline 1842 & 63500 & & 280 & 1350 & 1182 & 168 & 0.3 & \\
\hline 1843 & 63500 & & 358 & 1805 & 2039 & -234 & -0.4 & \\
\hline 1844 & 63500 & & 416 & 2085 & 2355 & -270 & -0.4 & \\
\hline 1845 & 63500 & & & 2109 & 1497 & 612 & 1.0 & \\
\hline 1846 & 63500 & & & 2531 & 1754 & 777 & 1.2 & \\
\hline 1847 & 63500 & & & 3005 & & & & \\
\hline 1848 & 63500 & & & 2580 & & & & 1.7 \\
\hline 1849 & 63500 & & 773 & 3788 & & & & \\
\hline 1850 & 63500 & & 724 & 3555 & & & & \\
\hline
\end{tabular}




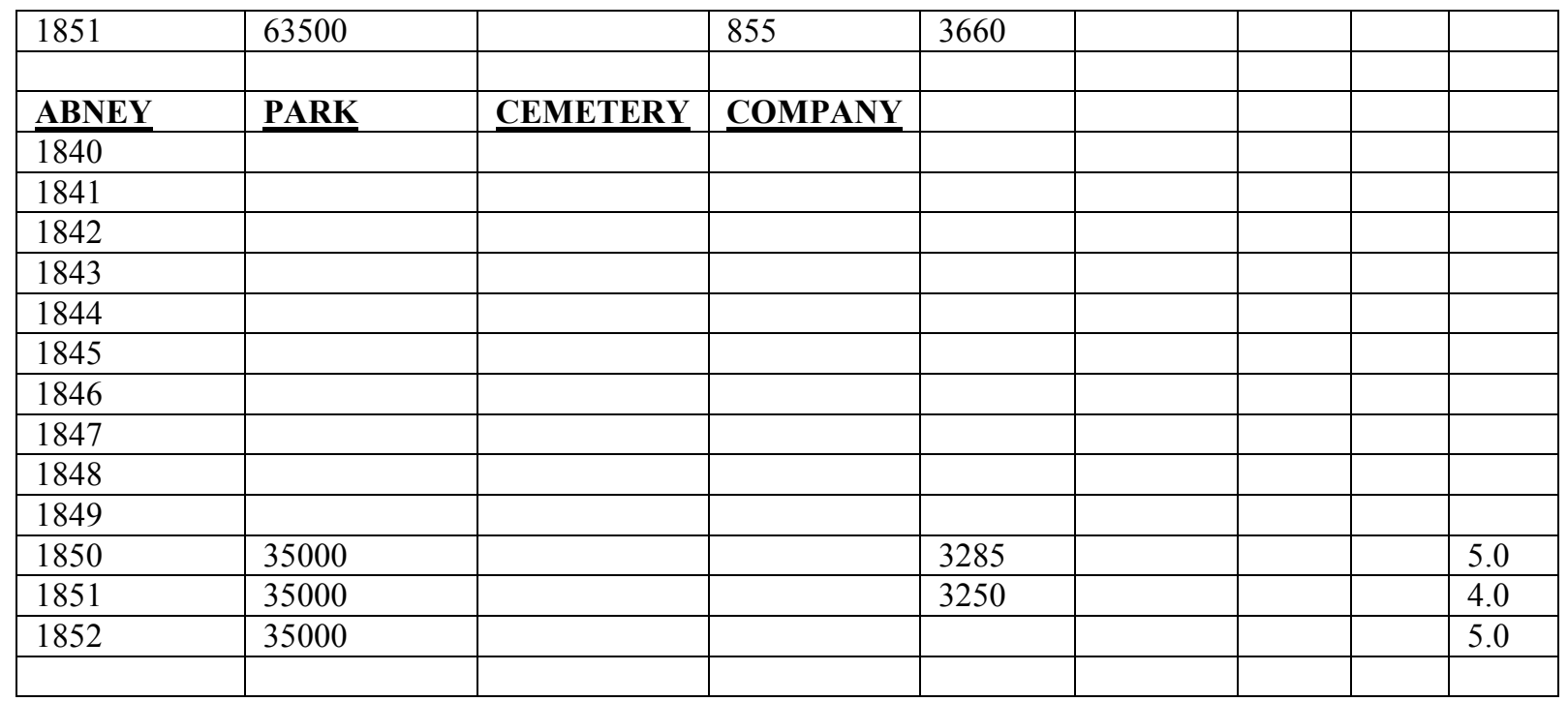

$\underline{\text { Sources: }}$

General Cemetery Company annual reports 1834-52, General Cemetery company offices South Metropolitan Cemetery Company ledger 1837-52, IV/100/AD/3/1

West of London Cemetery Company minute books, 1839-52, WORK 6/65-7, PRO Kew Abney Park Cemetery Company directors minute books 1850-2, D/B/ABN/1/26, Hackney Archives

${ }^{1}$ The quotation is from G K Chesterton (Whitfield, London: a Life, 145).

${ }^{2}$ Rugg, The Rise of Cemetery Companies, 10.

${ }^{3}$ Latham, The Illustrated Pepys, 72.

${ }^{4}$ Curl, The Victorian Celebration of Death, 32.

5 'In populous parishes, in large and crowded cities, the indulgence of an exclusive possession is unavoidably limited for, unless limited, evils of a most formidable magnitude take place ... [whereby] a comparatively small portion of the dead will shoulder out the living and their posterity'; Report on the Sanitary Conditions, 270-1.

${ }^{6}$ Schofield, 'British population change', 64-65, 67, 71, 89.

${ }^{7}$ Schofield, 'British population change' 89; Hobsbawm, Industry and Empire, 86.

${ }^{8}$ Rugg, The Rise of Cemetery Companies, 29; Report on the Sanitary Conditions, 189.

9 The library of the London School of Economics on Portugal Street, near Lincoln's Inn Fields, now occupies part of the site of the Green Ground; Kiloh, 'A Corner of London', 15-17. See also Pinfold, 'The Green Ground', 76-89.

${ }^{10}$ Keeling, 'The City of London', 118; Meller, London Cemeteries, 8-9; Jupp, 'Enon Chapel', 90-104.

${ }^{11}$ Harding, 'And one more may be laid there', 121.

${ }^{12}$ In practice this number reduced to about sixteen distinct offences, the rest being subdivisions of the same offences. In the eighteenth century, nearly two hundred offences carried the death penalty (including picking pockets and stealing bread) but Robert Peel and Elizabeth Fry were particularly influential in reducing this number.

${ }^{13}$ See Fido, Bodysnatchers, 8-11; Kesselring, 'Detecting death disguised', 20-26.

${ }^{14}$ Richardson, Death, 90; Guardian, 18 March 2006, 23.

${ }^{15}$ Richardson, Death, 85 . 
${ }^{16}$ Richardson, Death, 177, 183. Jeremy Bentham was the shining exception to the prevailing hypocrisy, leaving his body for dissection and embalming.

${ }^{17}$ After they were accused, Hare turned Kings Evidence and Burke was hanged and publicly dissected; see Fido, Bodysnatchers, 170-71.

${ }^{18}$ Wilson, British Business History, 23-25, 41-42.

${ }^{19}$ Foreman-Peck and Millward, Public and Private, 1-3, 10-11.

${ }^{20} 18$ \& 20 Vict. c. 47; Edwards A History of Financial, 92; Patterson and Reiffen, 'The Effect of the Bubble Act', 166; see also Cottrell, Industrial Finance, 8-10 and Hunt, The Development .

${ }^{21}$ Matthews 'Rogues, speculators'; Falkus, 'The British gas industry', 494-96; Falkus, 'The development of municipal', 139-41; Whitfield, London, 97.

${ }^{22}$ Falkus, 'The development of municipal', 139, 141-48; Matthews, 'Rogues, speculators', 39-40.

${ }^{23}$ Smellie, A History, 14-15, 23; Finer Municipal Trading, 299-302.

${ }^{24}$ Foreman-Peck and Millward, Public and Private, 4-12; Matthews 'Laissez-faire'.

${ }^{25}$ Smellie , A History,24-25, 149; Briggs Victorian Cities, 320-22.

${ }^{26}$ Foreman-Peck and Millward, Public and Private, 5-12.

${ }^{27}$ Carden had mounted an exhibition at the Royal Academy in 1824, proposing that a 'Pyramid

Cemetery for the Metropolis' be built at Primrose Hill; Friends of Kensal Green website, p. 2; see also Curl, 'Nunhead Cemetery', 32. The French had tackled the problem in Paris nearly a century earlier, closing all the city churchyards in 1765 and setting up four new cemeteries around the perimeter; Ross Williamson, 'Victorian Necropolis', 88.

${ }^{28}$ Keeling, 'The City', 120. The exception was Abney Park, whose founders objected on principle to consecration. It became a limited liability company by registration (rather than Act of Parliament) in March 1881.

${ }^{29}$ Coutts, 'Points of Entry', 62; Report on the Sanitary Conditions, 273.

${ }^{30}$ Coutts, 'Points of Entry', 62. Kensal Green was 54 acres (plus 15 acres acquired in 1853), Norwood 40 acres, Highgate 38 acres, Nunhead 52 acres, Brompton 39 acres (plus 5 acres bought in 1844), Abney Park 32 acres (the company also bought land for another cemetery at Chingford Mount, in Essex, in 1883) and Tower Hamlets 33 acres.

${ }^{31} 2$ \& 3 Will. c.110; 6 \& 7 Will. IV. c.136. By 1856 share capital inputs at the General Cemetery Company had risen to $£ 87,000$; annual report 1856 General Cemetery Company; directors minute books, Abney Park Cemetery Company D/B/ABN/1/1-2; minutes re general meeting and annual accounts June 1840, South Metropolitan Cemetery Company IV/100/AD3/1-2; see also Wilson, 'Norwood Cemetery', 17.

${ }^{32}$ Wilson, 'Norwood', 17.

${ }^{33}$ In the summer of 1839; Curl, Kensal Green, 121.

${ }^{34}$ Annual report 1837, General Cemetery Company, 5. In 1844, Brompton promoters acquired a further 4.5 acres of land that gave them valuable frontage onto Fulham Road; minute books West of London and Westminster Cemetery Company, WORK 6/65, 211; Stephenson, 'Brompton Cemetery', 5. 
${ }^{35}$ Curl, Kensal, 102; Stephenson, 'Brompton', 3; Curl, 'The Design', 223-54; Lambeth Borough, West Norwood; Manning, The Listed Structures.

${ }^{36}$ Smith, 'The South Metropolitan', 436.

${ }^{37}$ Keeling, 'The City', 121; papers of the Abney Park Cemetery Company BT 41/3/12; Joyce, A Guide, 39.

${ }^{38}$ Curl,'Nunhead', 34; Curl, Kensal, 17.

${ }^{39}$ Rugg, The Rise of Cemetery Companies, 24-25, 43-45, $205-07$.

${ }^{40}$ Stephenson, 'Brompton', 3.

${ }^{41}$ Rugg, The Rise of Cemetery Companies, 230-31.

${ }^{42}$ See, for example, the annual reports of the General Cemetery Company.

${ }^{43}$ General Cemetery Company Annual Report 1842, 8 .

${ }^{44}$ West of London and Westminster Cemetery Company minute books 1844, WORK 6/65-67, Public

Records Office, Kew; General Cemetery Company Annual Report May 1835, 4-5.

${ }^{45}$ Keeling, 'The City', 120-1.

${ }^{46}$ Abney Park Cemetery Trust website, 'History', 2.

${ }^{47}$ Curl, 'Nunhead', 40; Meller, London, 190; annual report 1842, General Cemetery Company, 8.

${ }^{48}$ Annual reports 1834-52, General Cemetery Company; ledger 1837-52, South Metropolitan Cemetery Company IV/100/AD/3/1; minute books 1839-54, West of London and Westminster Cemetery

Company WORK 6/65-67; directors minute books, Abney Park Cemetery Company D/B/ABN/1/1; papers of Abney Park Company BT 41/3/12.

${ }^{49}$ Curl, 'Nunhead', 44. See annual report 1835, General Cemetery Company, 5, for example.

${ }^{50}$ Annual reports 1839 and 1853, General Cemetery Company; Abney Park Cemetery Company directors minute books; Friends of Nunhead Cemetery, Nunhead Cemetery, 10; Curl, 'Nunhead', 36, 42-3; Keeling, 'The City', 120-1.

${ }^{51}$ The improvement was maintained; rates of return across the period 1850-90 averaged 6.3 per cent; ledger 1837-1873, minutes of general meetings and annual accounts 1864-1890, South Metropolitan Cemetery Company IV/100/AD/3/1, IV/100/AD3/1-2.

${ }^{52}$ Directors minute books 1850-59, Abney Park Cemetery Company D/B/ABN/1/26; Arnold and McCartney, 'Were they ever', 383-410.

${ }^{53}$ Stephenson, 'Brompton', 5; Jalland, Death in the Victorian, 196.

${ }^{54}$ Minute books, West of London and Westminster Cemetery Company, WORK 6/65, 232;

Stephenson, 'Brompton', 3. Curiously the largest shareholder, John Gunter, who owned half the shares, opposed the offer but was outvoted; company decisions were determined by a vote in which each shareholder had one vote, irrespective of the number of shares held; minute books, West of London and Westminster Cemetery Company, WORK 6/67. The company's own records show clearly that the claim was exaggerated and suggest a real level of capital expenditure of about $£ 97,000$; minute books, West of London and Westminster Cemetery Company, WORK 6/67, 22 October, 27 December 1851.

${ }^{55}$ Walker, Gatherings from Grave Yards, 201-2; see also Rugg, 'The Origins and Progress', 105-19. 
${ }^{56} \mathrm{Curl}$, The Victorian, 124. Thus, the proportionate number of deaths to the population ranged from 1 in 36 in St. Martins in the Fields (where over-crowding was particularly bad) to less than 1 in 50 in Kensington and Islington. Life expectancy could vary in some districts from 35 years for social class 1 to 21 years for social class 4, Report on the Sanitary Conditions, 189, 256-66; Report on the Improvement.

${ }^{57} 13$ \& 14 Vict. c.52; 15 \& 16 Vict. c.85; Pinfold, 'The Green Ground', 86-87;. Holmes, The London.

${ }^{58}$ London's first crematoria was opened at Golders Green in 1902.

${ }^{59}$ Highgate Cemetery is now controlled by Camden, Nunhead and Norwood by Lambeth, Tower Hamlets Cemetery by the local council of that name, while Abney Park is now a local Nature Reserve within Hackney. Kensal Green still functions as a private sector cemetery company and Brompton cemetery is under the control of the Royal Parks.

${ }^{60}$ Times, 11 October 2004, 26. The legal position governing burials in municipal cemeteries was clarified by the Local Authority Cemetery Order (1977), which restricted the right of burial in perpetuity, so that areas containing older graves could be reused for new burials.

${ }^{61}$ Observer Magazine, 2 April 2006, 20-27.

${ }^{62}$ Official returns made to the House of Commons in 1833 identified a figure of 32,412 interments in the burying places of the established churches in London (including Chelsea, Kensington, Saint Maryle-Bone, Paddington and St. Pancras in the county of Middlesex), to which must be added about 10,500 for the burial-grounds of Dissenters and Jews and general burial-grounds. These figures are broadly consistent with those for 1840-41, set out in the Select Committee report of 1843; see Report on the Sanitary Conditions, 274-79. See also Coutts, 'Points of entry', 62, Joyce, A Guide, 34 and Rugg, The Rise of Cemetery, 29.

${ }^{63}$ The first of the Bills, to establish a 'General Cemetery for the Interment of the Dead in the Neighbourhood of the Metropolis' was passed by Parliament in July 1832. The Reform Bill received its Royal Assent the previous month.

${ }^{64}$ Return of all Burial Grounds, 291-94.

${ }^{65}$ Report on the Sanitary Conditions, 267-69.

${ }^{66}$ Rugg, 229.

${ }^{67}$ Foreman-Peck and Millward, Public and Private, 5-12; Rugg, The Rise of Cemetery Companies, $229,236$.

${ }^{68}$ Curl, The Victorian, 112, 120-21. 